\title{
Sanatsal Düşüncenin Aktarımında Günlük Kullanım Nesnelerinin Değişen Rolü
}

\author{
The Changing Role of Daily Objects in Conveying of Artistic Thought
}

\author{
Tanzer Arrğ
}

Öğr. Gör. Hacettepe Üniversitesi Güzel Sanatlar Fakültesi Heykel Bölümü, tanzerarig@gmail.com

\section{$\ddot{\mathbf{O} z}$}

20. yüzyılın başından itibaren endüstri ve teknolojinin gelişmesine paralel seri üretimlerin hız kazandığ1 açıkça gözlemlenirken, insanın yaşantısını sürdürdüğü çevreyi daha çok kuşatmaya başlayan günlük kullanım nesneleri, sanat alanında da sanatçıların, çalışmalarında yoğunluklu olarak ele aldığı konu ve malzeme haline gelmeye başlamıştır.

$\mathrm{Bu}$ araştırmanın amacı sanatçıların seçimiyle kullanım nesnesi olmaktan sanat nesnesine dönüşmeye başlayan nesnelerin üretim amaçları dışında yeniden düzenlenmesi ve taşındıkları yeni bağlamlarıyla sanatsal çalışmaların gerçekleştirilmesinde nasıl etkin bir role kavuştuğu üzerine yoğunlaşmaktadır. Bu çalışmada gündelik kullanım için üretilen eşyaların değişen gerçeklikleriyle birlikte sanat alanında ne türden bir kavrayışa neden olduğuna yönelik gerekli kaynak taraması yapılmış, sanat alanındaki ilk örneklerinden başlayarak günümüze kadar uzanan süreçte yaşanan değişimler göz önünde bulundurularak kronolojik bir sıralama izlenmiştir. Dolayısıyla günlük kullanım nesnelerinin yaşamsal, zamansal vb. koşullara bağlı olarak gösterdiği değişimler göz önüne alındığında bugünde sanatsal düşüncenin aktarılmasında bir aracı olarak kullanılmaya devam etmelerinin ne derece önemli ve kaçınılmaz olduğunu ortaya koymaktadır.

Anahtar Sözcükler: Üretim Nesnesi, Eşya, İşlevsellik, Sanat Eseri, Zaman

\begin{abstract}
Since the beginning of the twentieth century, while it can be clearly observed that mass production gained a great deal of momentum parallel to the development of industry and technology, the objects of daily use that started to surround the living space, have also started to become the subject and material which the artists have dealt with intensively in their works.

The aim of this study is to focus on how the objects, which are transformed from being an everyday object of use, to an object of art by the artist's choice, acquired an effective role in the rearrangement other than their production purposes and the realization of works of art with their new contexts. In this study, the necessary references had been reviewed about what kind of understanding evoked in the field of art by the goods produced for everyday use with their changing realities and a chronological order was followed considering the changes in the process starting from the first examples in the field of art until today. Therefore, considering the transformation of objects of everyday use relative to vital, temporal etc. conditions, it shows how important and unavoidable it is that they continue to be used as an instrument in the transfer of artistic thought today.
\end{abstract}

Keywords: Production Object, Goods, Functionality, work, Time 


\section{Giriş}

İnsan doğayla karşılaşmasından başlayarak günümüze kadar uzanan süreçte sürekli olarak nesneler üretmeyi sürdürmüştür. Başlangıçta sadece doğanın zorlayıcı koşulları karşısında hayatta kalabilmek, yaşamsal ihtiyaçlarını karşılamak, kolaylaştırmak adına üretilen nesneler zamanla belirli gereksinimleri karşılamanın dışında üretildiği dönemin tarihsel, sosyal, kültürel, ekonomik, politik vb. yaşantısı hakkında bilgileri de ortaya koyan göstergelere dönüşür. Baudrillard bu dönüşümü "Nesneler Sistemi" adlı kitabında "teknolojik sistemden kültürel sisteme geçiş yapan nesneler" olarak açıklarken, nesneler ve insanlar arasında yaşanan diyalektik ilişkinin zaman içerisinde değişen yapısına dikkat çeker (Baudrillard, 2011, s. 14).

Artık nesneler tarafından çok daha fazla ve hızlı bir biçimde kuşatılmaya başladığımız günümüz dünyasında sahip olunan "şey”lerin sıradanlaştığı, daha az sahiplenildiği aşikârdır. Bugün, kullanım süreleri günden güne kısalan, çok daha seri bir biçimde yeni ve üst modellerinin üretildiği bir dünyada yaşamak durumunda kalan insanın, bir zamanların büyüleyici, geçmişle bağı bir arada tutan nesnelerinden, hızlı bir biçimde üretilip tüketilen nesnelerine uzanan tarihsel gelişimi sanat alanının da güncel konularından birini oluşturmaktadır. Bu durum günümüz sanat dünyasının baş döndürücü değişiminde varlığını sürdürmeye çalışan sanatçı içinde geçerliliğini korurken, kendiyle özdeşleştirdiği, kendinden, yaşantısından bir parça gibi gördüğü kimi eşya/eşyalar ile geçmiş ve bugünü bir araya getirme çabasıyla çok daha belirgin bir hale gelir.

Türk Dil Kurumu Güncel Türkçe Sözlüğünde eşya "Türlü amaçlarla kullanılan, insan yapısı, taşınabilir cansız nesnelerin bütünü” olarak ifade edilirken, zamana, ihtiyaçlara, taleplere vb. koşullara bağlı olarak sürekli değişen yapısı nedeniyle her dönem yeniden değerlendirilmesi gerektiğini de ortaya koymaktadır (Eşya ${ }_{2}$ t.y.). İnsanın varoluşundan itibaren hayatta kalmak, doğaya uyum sağlamak ve yaşantısını kolaylaştırmak için çeşitli aletler üretmesiyle başlayan insan-eşya ilişkisi bir noktada yararlılık düzeyinden bireyin farklı gereksinimlerine de karşılık vermeye başlamasıyla genişleyen bir tanıma sahip olmaya başlar.

Bilgin (2011, s. 9) eşyayı;

(...) çeşitli konum ve işlevlere sahip; insanlararası iletişim ve etkileşimin aracı, kültürel değerlerin ve yaşam tarzlarının taşıyıcısı, psişik ve fiziksel yatırımlarımızın nesnesi, yaşam dekorumuzun ögesi. İnsanın dış dünyayla etkisinde davranışının aracı. İnsanın dış dünyaya uzantısı, dışa açı1ımı ve genişlemeyi sağlayan araç-gereç. Doğaya egemen olma çabalarının aracı olduğu kadar sonucu. Eşyalar, sosyal bir mesaj. Kültürümüzün üzerine yansıdığı, kayıt edildiği ürünler. Türlülüklerinde ve biçimlerinde, kolay ve zor elde edilişlerinde, onları üreten toplumun mesajları, onlara sahiplenilen veya onları kullanan insanın kimliğinin göstergeleri. İnsan ile insan, bizimle diğerleri arasında bir köprü, bir vasıta olduğu kadar, iletişimi durduran, bizi diğerlerinden ayıran bir engel. İletişim kanalı, iletişim duvarı, iletişim mesajı, fiziksel dayanağı ve kanalı

olarak tanımlarken, insanın dış dünyayla (doğayla) olan ilişkisinde önemli bir yere sahip olan eşyaların tarihsel süreç içerisinde sadece kullanıma yönelik dar bir çerçevede değerlendirilmesinin eksik bir kavrayışa neden olacağına işaret etmektedir.

Asıl işlevinden soyutlayarak kendisinden bir parça olarak görmeye başladığı, yaşantısında daha özel bir yerde konumlandırdığı eşyalar aracılığıyla kişisel dünyasını yeniden inşa etmeye girişen bireyin bu eylem hali başka türden bir gerçekliği de işaret etmektedir.

Nesneler ve insanlar birbirine yakın bağlarla bağlanmış olup bu danışıklı dövüş çerçevesinde kendilerine atfedilen duygusal değer sayesinde evde yaşayan bir "kişilik" gibi algılanmaktadır. 
Çocukluk yıllarında yaşanılan evlerin insanların anılarında bu kadar derinlemesine yer etmesinin nedeni hiç kuşkusuz yaşanılan yer olarak adlandırılan mekânın sahip olduğu bu karmaşık yapı olup buraya belli bir şekilde yerleştirilen nesnelere atfedilen simgesel önemdir (Baudrillard, 2011, s. 22).

Bireyin yaratıcı edinimini harekete geçirmesi, kendini ifade edebilmesi ve dünyayı nasıl algıladığını ortaya koyması açısından sürekli iletişim halinde olduğu eşyalara yönelmesi, bu eşyaların insan yaşantısı üzerinde nedenli etkin olduğunun da göstergesidir. Dolayısıyla, nesneler dünyasında yaşanan değişimlerin sanata olan yansımaları da, günden güne çeşitlenen farklı ele alınış biçimleriyle daha fazla dikkat çeker hale gelmektedir.

\section{Yöntem}

Bu çalışma bir alan yazın (literatür) taramasıdır. Buna göre, gündelik kullanım için üretilen eşyaların değişen gerçeklikleriyle birlikte sanat alanında ne türden bir kavrayışa neden olduğuna yönelik gerekli kaynak taraması yapılmış, sanat alanındaki ilk örneklerinden başlayarak günümüze kadar uzanan süreçte yaşanan değişimler göz önünde bulundurularak kronolojik bir sıralama izlenmiştir.

\section{Seri Üretim Nesnelerinin Sanat Alanında Kullanımı}

İnsanın dış dünyayla olduğu gibi sanatla da köklü bir geçmişe sahip olduğu bilinmektedir. Başlangıçta gerçek ama bilinmeyen bir dünyaya egemen olmaya çalışan insanın büyülü bir şey olarak gördüğü sanat, değişen koşullar karşısında toplumsal ilişkilere yön veren, içinde yaşadığı dünyayı daha derinlikli kavraması, keşfetmesi için algılarını harekete geçiren önemli bir ifade gücüne sahip olmuştur. Sanatın insanın çevresini sürekli kuşatmaya devam eden nesnelerin gizli kalmış tözlerini ortaya çıkarmak gibi önemli bir işlevi de yerine getirdiği düşünüldüğünde, bir nesnenin genel geçer tanımının dışında, kişiden kişiye değişebilen algısal farklılıklarıyla da değerlendirilmesi önem arz eder.

Bir masayı sözlükteki gibi tanımladığım zaman ("üstünde yemek yemeye ya da yazı yazmaya yarayan üç-dört ayaklı yatay tabla..."), masanın neredeyse özüne ulaşmış gibi olabilirim doğallıkla; bu öze eşlik edebilecek bütün ilinekleri, ayaklarının biçimini, oymalarını ve benzeri şeyleri göz ardı ederim; ama bu yaptığım algılamak değil tanımlamak olur. Bir masayı algıladığım zaman ise, masanın işlevini yerine getirme biçimine ilgisiz kalmam ve beni ilgilendiren şey masanın tablasını kendine özgü taşıma biçimidir, yerçekimine karşı koyarken ayaklarından tablasına çıkan özgün devinimdir. Bir masayı öbürlerinden ayrı kılan da budur. Burada hiçbir anlamsız ayrıntı yoktur: ahşabın lifleri, ayaklarının biçimi, ahşabın rengi ve eskiliği, eskiliğini gösteren sıyrıklar ve oymalar ve "masa" sözcügünün anlamı, masanın şu anki varoluş kipini ete tene büründüren bütün "ayrıntılarından" ağdığı ölçüde ilgimi çeker (Merleau Ponty, 2010, s. 60).

Öncesinde dış dünyanın olduğu gibi yansıtılmasının hedeflendiği bir anlayışa sahip olan sanatın gerçekliği temsil yönteminde yaşadığı çeşitlenme, zamanla insanın nesnelere olan bakışını da değişime uğratmıştır. Yeni temsil yöntemlerinin oluşmasında sosyal-ekonomik yapı, yaşanan savaşlar, endüstri, bilim ve teknoloji vb. alanlarda yaşanan gelişmeler etkili olmuştur. Özellikle 20. yüzyılın başından itibaren üretim amacının dışına çıkarak sanat yapıtının bir parçasına dönüşmeye başlayan gündelik kullanım nesneleriyle gerçekleştirilen sanatsal çalışmalara daha sık rastlanılması artan üretimlerinin ve tüketimlerinin bir yansımasıdır. Bu dönemle birlikte; salt biçimsel bir kavrayışın ötesinde, düşüncenin ön plana çıktığı bir eylem haline dönüşmeye başlayan sanat, geleneksel malzeme ve biçimlendirme yöntemlerinin dışında çağın yenilikçi düşünce yapısının ortaya konduğu, farklı malzeme ve tekniklerin denenmeye başladığı bir görünüme kavuşur. Tabi ki bu değişimin gerçekleşmesinde Endüstri devrimin yaşama kattığı yeni malzeme ve teknik olanakların önemli bir yer tuttuğu belirgin bir biçimde göze çarpmaktadır. 
Endüstri devrimiyle birlikte üretim bandından hızlı bir biçimde gündelik yaşantıya katılan sayısız çeşitlilikteki nesne bir süre sonra sanatçıların çalışmalarını oluşturmakta sıklıkla başvurduğu bir malzeme olmaya, taşındıkları yeni bağlamları ile kendi gerçeklikleri dışında üzerinde farklı okumaların yapılmasına aracılık eden birer imge haline dönüşmeye başlamıştır.

İlk örneklerine kübist kolajlar da rastlanılan hazır malzemenin sanat alanında kullanılmasıyla gerçekleştirilen çalışmalar, çoğunlukla konularını günlük yaşamdan alan dış dünyaya (doğaya) ait bir gerçekliğin yansıtılmaya çalışıldığ 1 temsillerden farklı olarak ip, gazete, mukavva, tel vb. hazır malzemelerin bizzat kendisinin ya da bir fragmanının kullanıldığı yeni bir anlatım diline doğru yönelim göstermiştir. (Görsel 1)

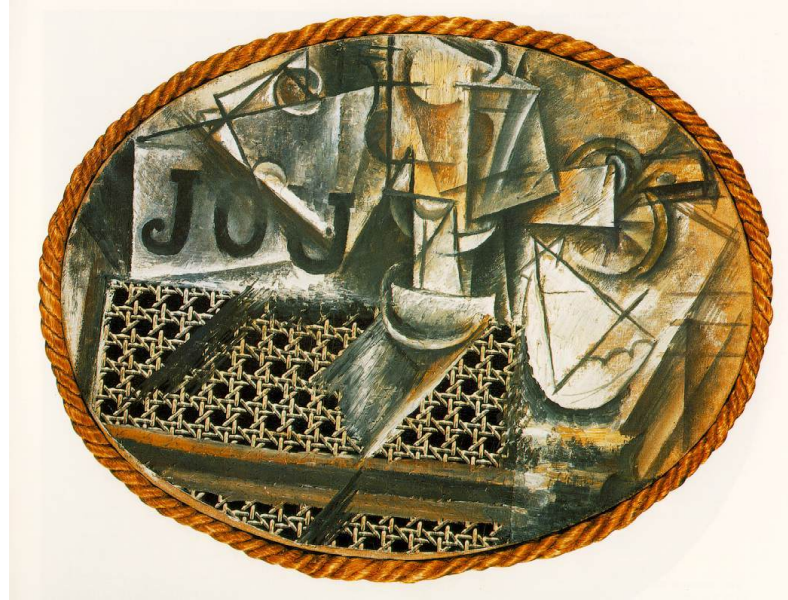

Görsel 1. Pablo Picasso, "Bambu Sandalyeli Natürmort”, 1912.

"Sanatı bir yetenek ve beceri eyleminden bir düşünme eylemine dönüştüren Dadayla, gündelik yaşamın sıradan nesnelerinin tüketim nesnesinden sanat nesnesi statüsüne evirilmeye başladığı durum, düşünsel olanın aktarımında da yeni stratejilerin ${ }^{1}$ ortaya çıkmaya başlandığının ilk sinyallerini de vermeye başlamaktadır" (Antmen, 2012, s. 125).

Duchamp'ın verdiği en basit tanıma göre bir hazır nesne "üretilmesi herhangi bir sanatçı gerektirmeyen bir iştir. Asıl önemlisi de bir başkaldırı eylemidir (...) sanatçıyı yüceltmektense toplumdaki statüsünün alçaltılmasıdır; onu kutsal kılan şeyin aşağılanmasıdır" (Lazzarato, 2017, s. 35).

Duchamp'ın ready-made'leri gündelik yaşantının dolaşımı içerisinde sıklıkla karşılaşılabilen Pisuvar, bisiklet tekeri, tabure vb. nesnelden oluşurken, sanat ve yaşam arasındaki bağın daha da birbirine yaklaşmaya başladığı bir dönemi işaret etmektedir. "Çeşme" adlı çalışmasında seri üretim bandından çıkan bir nesneyi (pisuvarı) herhangi bir biçimsel değişime uğratmadan sergileyen Duchamp'ın alışılmışın dışındaki bu eylemi², sanatın geleneksel yöntemlerini alaşağı etmenin yanı sıra metalaşmasına ${ }^{3}$ karşı eleştirel tavrını da göstermesi açısından önemlidir. Duchamp'ın gündelik kullanım nesnelerini düşünsel olanın aktarılmasında bir araç haline getirdiği yöntem, sonrasında Gerçeküstücülük, Pop-Art ve Fluxus gibi avangart sanat akımlarında da bir strateji olarak kullanılmasının temelini oluşturur.

\footnotetext{
${ }^{1}$ Hazır nesne bir tembel tekniğidir çünkü herhangi bir ustalık, özel uzmanlık, üretken faaliyet ve bedensel çalışma gerektirmez. Duchamp Çeşme (Fountain), Şişe Askılığı (Bottle Rack) ya da kar küreği gibi şeyleri "tembelin hırdavat dükkanının rafından" kolayca topluyordu; zaten bunları oraya yerleştiren de seri üretim ve kitlesel tüketimdi (Lazzarato, 2017, s. 35).

${ }^{2}$ Bana ilginç gelen şey (nesneyi) kendi pratik ya da faydacı içeriğinden söküp tamamen bomboş olan, dilerseniz genel anestezi diyebileceğim ölçüde her şeyden yoksun bir başka içeriğe yerleştirmektir (Lazzarato, 2017, s. 40).

${ }^{3}$ Duchamp sanatçının kapitalist ekonomiyle bütünleşmesini ve sanatın bir meta ya dönüşmesinin oldukça kesin ve ikna edici bir biçimde betimler: "Sanat tıpkı spagetti gibi satın alınıyor" (Lazzarato, 2017, s. 22).
} 
Bir sanat galerisinde bir pisuvar sergilemek eşi görülmemiş bir fikirdi ve bizatihi gerçekliği alt üst etmişti. Muhtemelen Duchamp'ın niyeti, Dada tarzında, sadece sanat kurumunu sarsmakt1ama olan sanata oldu; bu darbe, Duchamp'in cüretkâr resim denemeleri de dâhil olmak üzere sanat tarihinin çöküşünü hızlandırdı. Artık sanat realist mi, ekspresyonist mi, empresyonist mi yoksa fütürist mi olmalı, fovist, soyut, pop, minimal mi olmalı diye düşünmenin, 1şığ resmetsin mi resmetmesin mi veya kendi pisuvar iskeletini göstersin mi (Cezanne) göstermesin mi diye sormanın anlamı kalmamıştı. Her şey zihindeydi (...). Hazır nesne bir kalkış noktası değil, geri dönüşsüzlük noktasıydı (Baudrillard, 2014, s. 22).

Duchamp'la birlikte birçok sanatçı gündelik kullanım adına üretilen nesnelerin biçimi üzerinde oynayarak ${ }^{4}$ onları yeniden düzenlemekte, ikinci bir anlamlandırma düzlemine oturtmakta geç kalmamıştır. Kolaj, asamblaj, enstalasyon gibi farklı yöntemlerin de yardımıyla ait oldukları bağlamından koparılan nesneler, bir zamanların ustalık, beceri gibi kavramalar üzerinden adeta kutsadığı sanatını bambaşka bir boyuta taşmıştır. Artık eskinin göz alıcı, kusursuz formlarının yerini daha çok gündelik hayatın sıradan nesneleri üzerinden gerçekleştirilen çalışmalar almaya başlarken, insanlar ve eşyalar arasında yeni deneyimlerin önünün de açılması hız kazanmıştır. (Görsel 2-3)

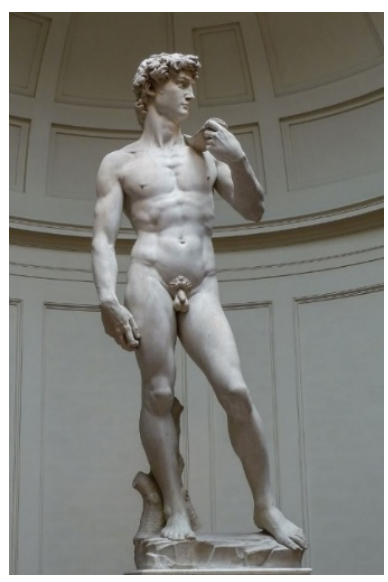

Görsel 2. Michelangelo, "Davut”, 1504

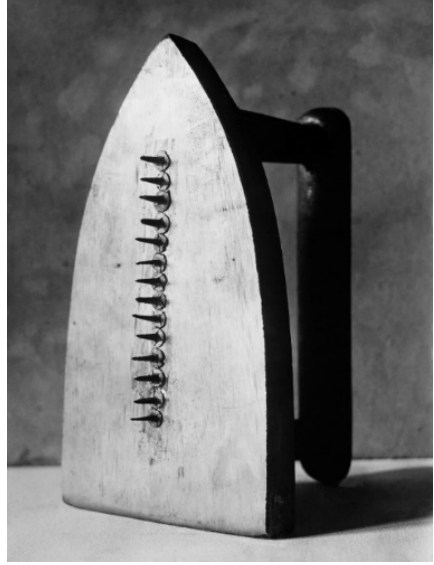

Görsel 3. Man Ray, “Hediye”, 1921

Nesneye ilişkin bakışı değiştiren bu müdahalelerle işlevinden uzaklaşmaya başlayan birçok kullanım nesnesi, sosyal statüyü işaret eden, güç ve saygınlığın sembolü, ekonomik, siyasi, politik, kültürel yapının göstergesi gibi yan anlamları üzerinden yeniden kurgulanarak sanatsal uygulamalarda kullanılmaya başlar.

Man Ray'in "Hediye" isimli çalışması da "Giysilerin, kumaşların buruşukluklarını ortadan kaldırmak" üzere üretilmiş bir ütünün sanatçının müdahalesiyle yapıcı olma eyleminden yıkıcı olana doğru evrildiği, üzerine eklenen çivilerle birlikte artık bir düzene değil düzensizliğe, karmaşaya ve tahribata işaret eden bir göstergeye dönüşümünü işaret eder. Söz konusu ütü işlevselliğini yitirdiği gibi alış1la geldik görüntüsünü de kaybetmiştir.

...Şeyler, karşısında düşünüp taşınacağımız yalın ve tarafsız nesneler değiller; her biri bizim için bir tutumu simgeler, bir tutumu anımsatır, bizde olumlu olumsuz tepkiler uyandırır; bir insanın kendisini çevrelediği nesnelerden, yeğlediği renklerden, dolaşmaya gittiği yerlerden, o insanın zevki, kişiliği, dünyaya ve dışardaki varlıklara karşı tutumu okunur (Merleau Ponty, 2010, s. 30).

\footnotetext{
${ }^{4}$ Meret Oppenheim'ın kürkle kaplı fincan ve tabaktan oluşan 1936 yapımı "Nesne" adlı çalışması farklı iki nesneyi bir araya getirerek oluşturduğu eklektik nesnesi, Picasso'nun 1943 y1lında gerçekleştirdiği, bisiklet selesi ve gidonundan oluşturduğu "Boğa Başı" adlı çalışmalar gibi çalışmalar örnek olarak verilebilir.
} 
Artık nesneler sadece biçimsel ve/veya işlevsel açıdan değerlendirilmenin ötesinde, kendi gerçeklikleri dışında başka bir gerçekliği temsil edebilmektedir. Modernizm nesneyi odak noktası olarak aldığı, kimi zaman parçaladığı, kimi zamanda başka nesnelerle bir araya getirerek yeni bir anlatıma kavuşturduğu birbirinden bağımsız farklı denemelerin gerçekleştiği bir dönemi işaret ederken, aynı zamanda kendisinden sonraki dönemde de nesnenin değişmeye, dönüşmeye devam edeceğinin sinyallerini verir.

20. yüzyılın ikinci yarısı, sanatta alternatif arayışların ardı ardına gerçekleştiği, Soyut Dışavurumculuk, Minimal Sanat, Pop Sanat ve Kavramsal Sanat gibi farklı yaklaşımların etkili olduğu bir dönemdir. Artur Danto dönemin sanatsal yaklaşımını Rauschenberg'in 1950'li yıllarda gerçekleştirdiği bir seri çalışma ${ }^{5}$ üzerinden ifade ederken, içerisinde bulunulan zamanda sanatın ne denli büyük bir değişim içerisinde olduğunu gösterir. "Gerçeklik, sanatın temsil etmesi gereken şeyken sanatın içine dâhil olunca, sanata atfedilen anlam da değişikliğe uğramıştır" (Danto, 2013, s. 33). Gündelik kullanım için üretilen eşyaların sanat eserine dönüşümü sürecini de etkileyen bu durumda, nesneler bir yandan sahip olduğu kimliğini korurken bir yandan da yeni bir kimliğe kavuşmaya başlar. Bir zamanlar Platon'un idealar dünyasının dokunulmaz nesnesi, pop sanatla birlikte nesneye dokunan, onu kullanan, dönüştüren, günlük yaşamdaki yerini sanatsal düzleme çeken bir durumla karşı karşıya kalır (Kahraman, 2002, s. 12). (Görsel 4)

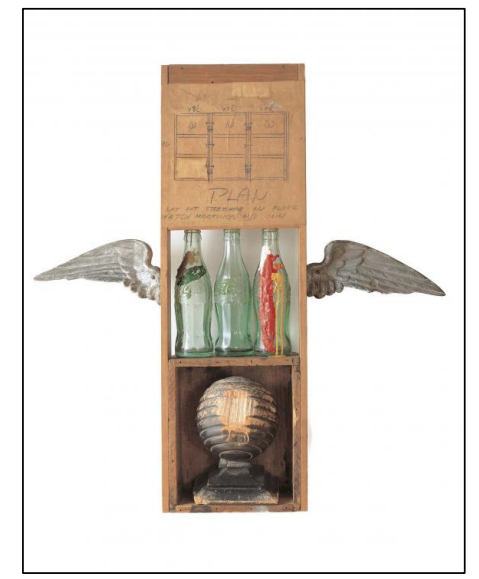

Görsel 4. Robert Rauschenberg, "Coca-Cola Tasarisi”, 1958

Pop Sanatın önemli temsilcilerinden biri olan Andy Warhol'un tüketim kültürünün popüler imajlarını kullanması da bir rastlantının sonucu değil, bilinçli bir düşüncenin ürünüdür. Sanatçı çalışmalarında konu edindiği Brillo kutularını, Campbell çorba tenekelerini vb. gerçeklerine olabildiğince benzer şekilde üreterek, sanat ve gerçeklik arasındaki algısal farklılıkları ortaya koymayı hedefler. Bu bağlamda Warhol kendini bir makine ${ }^{6}$ olarak tanımlarken, gerçekleştirdiği çalışmalarını da üretim bandından çıkan nesneler gibi izleyiciye aktarır. Warhol'la birlikte öncesinde biricik, ulaşılması, anlaşılması zor olarak sanatsal imge, mekanik şekilde çoğaltılabilen, derinlikli bir okumaya ihtiyaç duyulmadan, herkesin yaklaşabileceği, ilişki kurabileceği bir nesne haline dönüşür.

Warhol'un sergisi için içeriye girdiğinizde, yanlış bir yere girdiğiniz izlenimine kapılıyordunuz. İçerisi bir süpermarket deposundan farksızdı. Tüm mobilyalar kaldırılmıştı, her yerde itinayla yerleştirilmiş sıra sıra kutular vardı: Brillo, Kellogg's, Del Monte, Heinz vb. Galeriden kutu satın alan şanslı izleyiciler, ellerinde torbaya sarılmış kutularla sokakta yürürken herkesin dikkatini çekiyordu. Kutular dışarıdan bakıldığında birbirinin tamamen aynısıydı. Bana kalırsa gözle

\footnotetext{
${ }^{5}$ Raushenberg'in çalışmaları, yorgan, Coca Cola şişeleri, araba lastikleri ve dondurulmuş hayvanlar gibi farklı malzemelerden oluşmaktadır.

6 "Makine olmak istiyorum". Bu söz genellikle Warhol'un ve onun sanatının anlamsızlığını doğrulamakta kullanılır; fakat anlamsızdan çok, şok geçiren bir özneyi işaret eder gibidir. Özne bu şoka karşı mimetik bir savunma olarak kendisini şok edenin doğal görünümüne bürünür: Ben de bir makineyim, ben de seri üretim imgeleri oluşturuyorum (veya tüketiyorum), ben de aynisinı yapıyorum (Foster, 2009:166).
} 
görülür hiçbir fark olmadığına göre mutlaka görünmez farklar olması gerekiyordu-söz konusu görünmezlik, Brillo kutularının içindeki Brillo süngerleri anlamında değil, daimi olarak görünmez kalan nitelikler anlamındadır (Danto, 2013, s. 46-47).

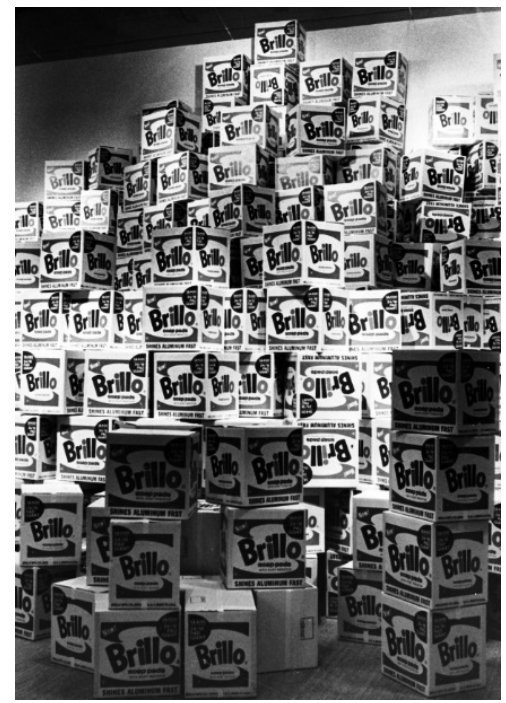

Görsel 5. Andy Warhol, “Brillo Kutuları”, 1964.

Warhol, Stable Gallery'de açtığı sergide ki çalışmalarını sıradan bir marketteki ürünleri sergileme mantığıyla benzer bir biçimde kurgularken, çalışmasında Brillo, Kellogg's, Del Monte, Heinz gibi dönemin hâlihazırda üretim-tüketimde olan markalarını kullanması bilinçli olarak tercih eder. Böylece izleyicinin bir sanat eserine yaklaşırken yaşadığı tedirginlik, bilindik imajlar ve sergileme biçimi sayesinde asgari seviyeye çekilirken, sanat eseri tıpkı endüstriyel bir ürün gibi kolayca alınıp satılabilir bir obje gibi izleyiciye sunulur. (Görsel 5)

Yeni dünya düzeninin ekonomi ve küreselleşme üzerinden kurulmaya başlandığg 1980'lerden itibaren ise Jeff Koons, Haim Steinbach gibi sanatçılar özellikle dönemin popüler markalarından seçtikleri elektrik süpürgesi, basketbol topu, ayakkabı, çalar saat gibi herkesin rahatlıkla bir mağazadan satın alabileceği ürünleri birer sanat eseri olarak müze ve galerilerde izleyiciyle buluşturur. "Yeni İki Katlı Islak/Kuru Shelton", "Fevkalade Kırmızı II" gibi çalışmaların dönemin popüler imajlarından oluşması, izleyicinin güncel yaşantısında hali hazırda kullanımındaki nesneler olması nedeniyle çok daha kolay iletişim kurabilmelerini sağlamaktadır. (Görsel 6-7)

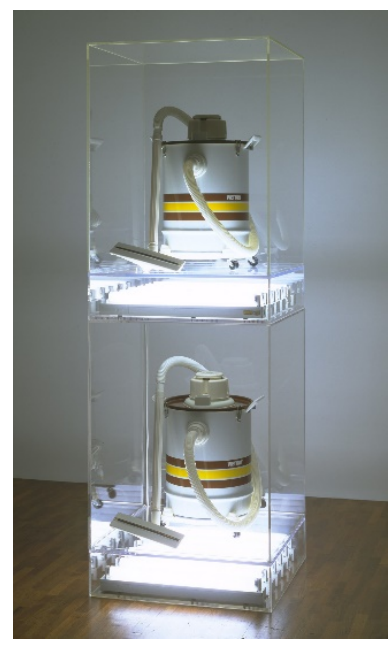

Görsel 6. Jeff Koons, "Yeni İki Katl Islak/Kuru Shelton", 1981

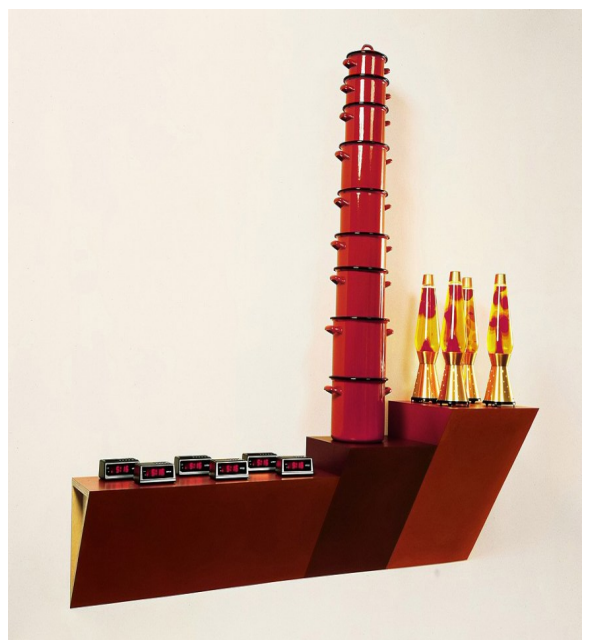

Görsel 7. Haim Steinbach, “Aşırı Kırmızı No:2”, 1986. 
Koons çalışmalarını, Sanatım, izleyiciyle iletişim kurmak adına her türlü yola başvurur. İzleyicinin ilgisini çekebilmek için her türlü hileye, ne gerekiyorsa, ama ne gerekiyorsa başvurmaya hazırım. En saf ve yüzeysel kişiler bile benim sanatım karşısında kendilerini tehdit edilmiş hissetmezler, karşılarında gördükleri şeyi anlayamadıkları, anlayamayacakları bir his yaşamazlar. Bakarlar ve hemen onunla bir ilişki kurarlar. Ayrıca çok iyi eğitim görmüş daha derinlemesine bakabilen bir kişi de yapıtlarıma bakıp, yaşadığımız kültüre nasıl bir katkıda bulunduğunu görebilir. Yapıtlarımla, insanların gereksinimlerine seslenmek istiyorum. İnsanları kendi kültürlerinden uzaklaştıran, onları bloke eden sınırları yok etmek istiyorum. Benim yapıtlarım insanlara bir ilişki kuramadıkları şeyler onları etkisi altına alıyormuş gibi değil, o anı kucaklamalarını sağlar. Bir şeye inanmalarına ve o inancı göstermelerine yardımcı olur (Antmen, 2012, s. 293) olarak tanımlarken, güncel yaşantının bilindik nesnelerini birer meta heykele ${ }^{7}$ dönüştürür.

$\mathrm{Bu}$ çalışmalar bir yandan nesnenin kendi özüne ait aurasını kaybetmesine neden olabildiği gibi bir yandan da yeni bir öze kavuşmasını sağlamaktadır. Koons meta göstergelerin yapay veya fetişsel yanıyla ilgilenirken, Steinbach onun farka dayanan ve kodlanmış yönüne eğilir... Kültürel olanın sanatın kaybolan aurasını meta ve starların "düzmece büyüsüyle" kapatması gerekir (Foster, 2009, s. 146).

Hasan Bülent Kahraman ise sanatın geldiği bu durumu kitle üretim mantığına bağlarken, Kitle üretiminin mantığı, bir tür imgelerin imgeler aracılığıyla üretimidir. Nesnenin kendisi, kitle üretimi içinde, kendi gerçekliğinden soyutlanmıştır. Çünkü nesne, artık Batılı bilinç tarafından ona ait gerçekliğiyle, kendisine ait varoluşuyla, hatta kendisine ait somutluğuyla algılanmaktadır. Nesne, Batılı bilinçte bir imgeler yığınıdır. Kitle iletişim araçlanıla sunulan fakat reklamcılık sektörünün geliştirdiği ve her nesneyi bir imgeyle somutlaştırmaya yönelik mantık bugün o toplumlarda yaşayan insanı tutsak etmiştir. Batılı insan nesneleri, böylelikle, kendi bağlamlarından kopararak algılarken iki boyutlu bir tüketim gerçekliğini yaşamaktadır. Bir yandan doğrudan nesneyi tüketmekte, bir yandan da nesnenin imgesini soğurmakta, sonra da tüketmektedir (Kahraman, 2002, s. 13).

Eşyalarında insanlar gibi dünyada belli bir varoluşa, belli bir tarihsel, kültürel, sosyolojik vb. geçmişe sahip olmaları, zamana ve değişen koşullara bağlı olarak her dönemde yeniden ele alınmalarını gerektirmektedir. Algısal farklılıklarıyla insani karakterlere bürünebilen, kendi başlarına ya da diğer eşyalarla biraradalıkları üzerinden ilişkilendirilebilen kimi eşyalar, aynı zamanda bireye özgü duygu ve düşüncelerin taşıyıcısı, aktarıcısı gibi işlevleri görebilmektedir.

\section{Kişisel Dünyanın Ayrıcalıklı Nesneleri Üzerinden Sanatsal Düşüncenin Aktarımı}

Sanatçının içinde yaşadığı dünyanın sıradan nesneleri dışında kendi yaşantısında özel bir yerde konumlandırdığı kimi nesneleri düşünsel anlatımının bir aracısına dönüştürmesi, sanatsal sürecine dâhil etmesi, taşıdıkları anlam yükünün yanı sıra belirli bir zamanı işaret ediyor olmaları açısından önem kazanmaktadır. Geçmiş ve bugünü aynı düzlemde buluşturabilen bu eşyalar, birer imge durumuna geçerken, anı, yaşanmışlık gibi kavramlar üzerinden sanatçının olduğu kadar izleyicinin de duygu ve belleğini harekete geçirmeye çalışır.

Sarkis'in 1986 yılında Maçka Sanat Galerisinde gerçekleştirdiği "Çaylak Sokak" adlı yerleştirmesi de kişisel eşyaların sanatsal anlatımda kullanılması açısında önemli bir örnektir. (Görsel 8)

Sanatçı bu yerleştirmesinde çocukluk anılarını taşıyan nesnelere yer vermiş, dayısının kunduracı tezgâhı ona yedi yaşındayken bu tezgâhta çalıştı̆̆ını, üstüne film bantlarıyla bir figür oluşturduğu teyzesinin radyosu da ilk kez dinlediği müziği anımsatmaktadır. Dayısının içinde domates ektiği

\footnotetext{
${ }^{7}$ Meta Heykel, satın alınmış eşyalarla yapılan heykel (Foster, 2009:140).
} 
bebeklik banyosunu galeriye getirmiş ve içine bir balıkçı teknesi maketi koymuş, üstüne de Tarkovski'nin Nostalgia adlı filminin bantlarını bir kadın heykelini anımsatır biçimde yerleştirmiştir. Ayrıca artık yürüyemeyen babasının işlevini yitiren ayakkabılarını, 1963'te yaptığı bir tabloyu ve Çaylak Sokak levhasını da aynı mekâna taşımıştır (Atakan, 2008, s. 96).

Söz konusu eşyalar üretim amaçlarının dışında, sanatçının geçmiş yaşantısının izlerini, belleğini bugüne taşıyan, yeniden canlandıran, dış dünyayla iletişiminde aracılık eden nesneler olarak yeni bir varlık düzlemine taşınır. Sarkis, "belleği olan bir ayna"8 gibi hareket ederken, sesin işlendiği teyp bantlarındaki kayıtlar gibi belleğinde yer edinmiş anılarını da kişisel dünyasının eşyaları üzerinden bugünde yansıtır.

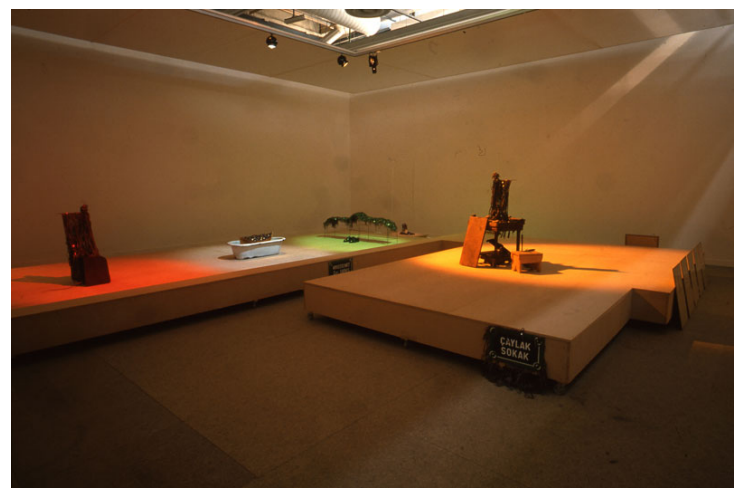

Görsel 8. Sarkis Zabunyan, “Çaylak Sokak”, 1989

Kişisel eşyaların sanat nesnesi haline dönüşümünün farklı bir örneği olarak Tracey Emin'in "My Bed / Yatağım" adlı çalışması verilebilir. Sanatçının çalışması yaşantısına ait bir anın galeri mekânında yeniden düzenleyerek izleyiciye sunulması üzerinden hareket eder. Bu çalışmada kullanılan tüm nesneler Emin'in cinsel deneyimlerinin, geçmişinde yaşadığı kötü anılarının bir göstergesi olarak sanatsal bir objeye dönüşür. Emin, galeri mekânında kurmaca bir görüntü oluşturmak yerine bizzat kendisi tarafından kullanılmış olan nesneleri (dağınık yatağı, ilaç kutuları, içki şişeleri, sigara izmaritleri vb.) tıpkı geçmişte olduğu gibi yerleştirerek çalışmasına dâhil ederken, galeri mekânında işle karşılaşan izleyici, geçmişte yaşanan anların canlı bir tanığına dönüşür. (Görsel 9)

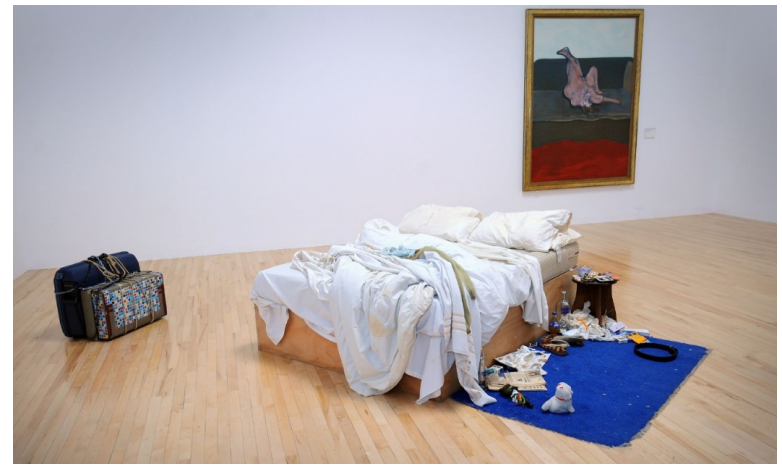

Görsel 9. Tracey Emin, “Yatağım”, 1998

Rachel Whiteread, Sarkis'in çalışmasında olduğu gibi kişisel eşyaların belli bir kurgu içerisinde düzenlendiği ya da Tracey Emin'in geçmiş bir anın görüntüsünün gerçek nesneler kullanılarak galeri mekânında sergilediği çalışmalardan farklı olarak, yaşantısında belirli bir ana, yaşanmışlığa tanıklık eden kişisel bir eşyanın bizatihi kendisini değil kalıbını kullanarak oluşturur. Whiteread seçimlerinde genellikle kişisel geçmişine göndermeler yapan nesneleri kullanmayı tercih ederken, bu nesneleri negatif-pozitif ilişkisinde kurgular.

\footnotetext{
8 “Belleği Olan Bir Ayna” (Draasima, 2014, s. 143).
} 


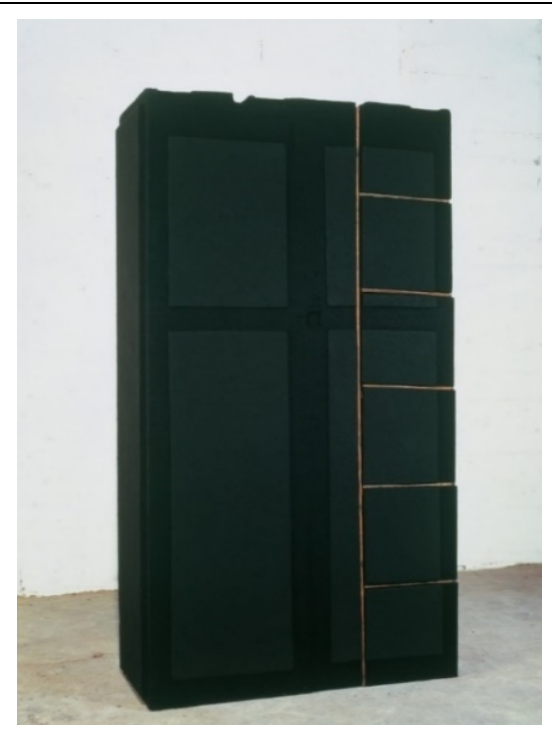

Görsel 10. Rachel Whiteread, "Dolap”, 1988

Closet (Dolap) adlı çalışması da bir zamanlar ailesiyle birlikte yaşadığı evin yatak odasında yer alan elbise dolabının iç boşluğunun kalıbı alınarak gerçekleştirilmiştir. Sanatçı aldığı kalıbı siyaha boyayarak sergilerken, izleyiciyi dolabın kendisiyle değil, içindeki boşlukla karşı karşıya bırakmayı amaçlar, söz konusu durumda izleyici karşılaştığ tarafından kitlendiği dolabın içindeki karanlıkta yaşadığı korku dolu o anı deneyimler. (Görsel 10)

Sanatçıların düşüncelerini somut formlara dönüştürürken biçim, malzeme gibi konularda sınırları ne kadar zorladığına önemli bir örnek teşkil eden Whiteread'ın bu çalışması, aynı zamanda nesnelerin gündelik kullanım amaciyla üretiminden başlayarak sanatsal bir imgeye dönüşmesinden, bir noktada yok olmaya kadar uzandığı durumunu gözler önüne serer.

Hızla değişen dünyada kendini ifade edebilmenin farklı yollarını arayan birçok sanatçı, çevresinde yer alan ve sürekli temas halinde olduğu nesneleri öncelikli tercihlerinden biri olarak ele almayı günümüzde de sürdürmeye devam etmektedir.

\section{Sonuç}

Sanayi Devrimiyle birlikte nesne üretimindeki artışın toplumsal yaşantıyı etkilediği gibi sanat ortamını da büyük oranda etkilediği gözlemlenirken, kendini günden güne artan nesneler tarafindan hızla kuşatılmaya başladığı bir dünyada konumlandırmak durumunda olan sanatçının bu değişimler karşısında varlığını sürdürebilmek, kendini ifade edebilmek için nesnelere yönelmesi kaçınılmaz hale gelmiştir. Özellikle 20. yüzyılın başından itibaren sanatın geleneksel malzeme ve biçimlendirme yöntemlerine alternatif, teknolojinin sunduğu yeni malzeme ve teknik olanaklarla üretimlerin gerçekleştirildiği sanatsal çalışmalara gerek galeri mekânında gerekse kamuya açık alanlarda daha fazla rastlanılmaya başlanması bu durumu doğrular niteliktedir.

Gündelik kullanıma yönelik üretilen nesneler kimi zaman kullanım alışkanlıklarının, fiziksel ya da işlevsel yapılarının, meta değerlerinin vb. dışında, belleğe ve belirli bir zamana işaret edebilmeleriyle, kişisel dünyanın ayrıcalıklı nesnelerine de dönüşebilmektedir. Bu nesneler geçmiş yaşantının tanıkları olarak bellekte yer edinirken, taşıdıkları anlam yükü daha da zenginleşmekte, sanatsal düşüncenin bir aracı olarak geçmişte olduğu gibi günümüzde de birçok sanatçı tarafindan tercih edilmeye devam etmektedir.

Sanat ve gerçekliğin, gerçekle imgenin çok daha belirgin bir biçimde iç içe geçtiği gözlemlenen 20 . yüzyılın ikinci yarısından itibaren gündelik yaşantıda kullanılmak üzere üretilen dolayısıyla da tüketilen 
nesnelerin sanatçılar tarafından çok daha farklı bir biçimde ele alındığ 1 bir dönem olmuştur. Birçok sanatçının satın aldıkları ya da çöplükten, sokaktan topladıkları malzemelerle tüketim kültürünün sebep olduğu toplumsal karmaşayı güçlü bir biçimde eleştiren çalışmalar gerçekleştirmeye başlamasından, izleyicinin galeri mekânında hiçbir biçimsel değişime uğratılmadan sergilendiği gündelik hayatın sıradan nesneleriyle birer sanat eseri olarak karşılaşmasına, galeri mekânına bırakılmış bir çöp yığını zannedilip atıldığı gibi farklı örneklere rastlanılması, seri üretim nesnelerinin sanat alanında geldiği noktayı göstermesi açısından önemlidir.

\section{Kaynakça}

Antmen, A. (2012). 20. Yüzyll Batı Sanatında Akımlar. İstanbul: Sel Yayıncılık.

Atakan, N. (2008). Sanatta alternatif arayışlar (Z. Rona, Çev.). İzmir: Karakalem Kitabevi.

Baudrillard, J. (2011). Nesneler sistemi (O. Adanır ve A. Karamollaoğlu, Çev.). İstanbul: Boğaziçi

Baudrillard, J. (2014). Sanat komplosu (I. Ergüden, Çev.). İstanbul: İletişim Yayınları.

Bilgin, N. (2011). Eşya ve insan. İstanbul: Gündoğan Yayınları.

Danto. A. (2013). Sanat nedir? (Z. Baransel, Çev.). İstanbul: Sel Yayıncılık.

Draaisma, D. (2014). Bellek metaforları (G. Koca, Çev.). İstanbul: Metis Yayınları.

Eşya. (t.y.). Türk dil kurumu güncel Türkçe sözlüğü. Erişim adresi: http://tdk.gov.tr/index.php?option=com_gts\&arama=gts\&guid=TDK.GTS.5c7252ef858196.919 01182

Foster, H. (2009). Gerçekliğin geri dönüşü (E. Hoşsucu, Çev.). İstanbul: Ayrıntı Yayınları.

Kahraman, H. B. (2002). Sanatsal gerçeklikler, olgular ve öteleri. İstanbul: Everest Yayınları.

Lazzarato M. (2017). Marcel Duchamp ve işin reddi (S. Çalc1, Çev.). İstanbul: Kolektif Kitap.

Merleau-Ponty, M. (2010). Algllanan dünya (Ö. Aygün, Çev.). İstanbul: Metis Yayınları.

\section{Görsel Kaynakçası}

Görsel 1. Picasso, P. (Sanatç1). (1912). Bambu Sandalyeli Natürmort / Still-Life with Chair Caning [Kolaj]. Erişim adresi: https://perezartsplastiques.com/2017/06/26/nature-morte-a-la-chaisecannee-picasso-1912/

Görsel 2. Michelangelo. (Sanatçı). (1504). Davut /David [Heykel]. Erişim adresi: https://tr.wikipedia.org/wiki/Davut_(Michelangelo)\#/media/File:\%27David\%27_by_Michelang elo JBU0001.JPG

Görsel 3. Ray, M. (Sanatç1). (1921). Hediye / Gift [Heykel]. Erişim adresi: https://thewire.in/culture/man-ray-photograph-exhibition

Görsel 4. Rauschenberg, R (Sanatçı). (1958). Coca-Cola Tasarısı / Coca-Cola Plan [Heykel]. Erişim adresi: https://www.rauschenbergfoundation.org/art/artwork/coca-cola-plan

Görsel 5. Warhol, A. (Sanatçı). (1964). Brillo Kutuları / Brillo Box [Heykel]. Erişim adresi: https://78.media.tumblr.com/tumblr_m0ahwxWgOm1qbo39mo1_1280.jpg

Görsel 6. Koons, J. (Sanatç1). (1981). Yeni İki Katlı Islak/Kuru Shelton / New Shelton Wet/Dry Doubledecter [Heykel]. Erişim adresi: https://www.moma.org/collection/works/81090

Görsel 7. Steinbach, H. (Sanatçı). (1986). Aşırı Kırmızı No:2 / Ultra Red No:2 [Heykel]. Erişim adresi: https://www.guggenheim.org/artwork/3997 
Sanatsal Düşüncenin Aktarımında Günlük Kullanım Nesnelerinin Değişen Rolü

GSED 42 - DOI: 10.32547/ataunigsed.482661

Görsel 8. Zabunyan, S. (Sanatçı). (1989). Çaylak Sokak [Enstelasyon]. Erişim adresi: http://www.sarkis.fr/1989-les-magiciens-de-la-terre/

Görsel 9. Emin, T. (Sanatçı). (1998). Yatağım / My Bed [Enstelasyon]. Erişim adresi: https://mollyharcombe.files.wordpress.com/2015/11/78b9a265-b28d-4bae-8b78-fde72d95d60b2060x1236.jpeg

Görsel 10. Whiteread, R. (Sanatçı). (1988). Dolap / Wardrobe [Heykel]. Erişim adresi: http://www.ggart.com/news/photoshow/4300916.html 